\title{
Dietary sardine protein lowers insulin resistance, leptin and TNF- $\alpha$ and beneficially affects adipose tissue oxidative stress in rats with fructose-induced metabolic syndrome
}

\author{
ZOHRA MADANI $^{1}$, KARIM LOUCHAMI $^{2}$, ABDULLAH SENER $^{2}$, WILLY J. MALAISSE $^{2}$ and DALILAAIT YAHIA ${ }^{1}$ \\ ${ }^{1}$ Department of Biology, Es-Sénia University, Oran, Algeria; ${ }^{2}$ Laboratory of Experimental \\ Hormonology, Université Libre de Bruxelles, Brussels, Belgium
}

Received August 15, 2011; Accepted October 25, 2011

DOI: $10.3892 /$ ijmm.2011.836

\begin{abstract}
The present study aims at exploring the effects of sardine protein on insulin resistance, plasma lipid profile, as well as oxidative and inflammatory status in rats with fructoseinduced metabolic syndrome. Rats were fed sardine protein (S) or casein (C) diets supplemented or not with high-fructose (HF) for 2 months. Rats fed the HF diets had greater body weight and adiposity and lower food intake as compared to control rats. Increased plasma glucose, insulin, HbA1C, triacylglycerols, free fatty acids and impaired glucose tolerance and insulin resistance was observed in HF-fed rats. Moreover, a decline in adipose tissues antioxidant status and a rise in lipid peroxidation and plasma TNF- $\alpha$ and fibrinogen were noted. Rats fed sardine protein diets exhibited lower food intake and fat mass than those fed casein diets. Sardine protein diets diminished plasma insulin and insulin resistance. Plasma triacylglycerol and free fatty acids were also lower, while those of $\alpha$-tocopherol, taurine and calcium were enhanced as compared to casein diets. Moreover, S-HF diet significantly decreased plasma glucose and HbA1C. Sardine protein consumption lowered hydroperoxide levels in perirenal and brown adipose tissues. The S-HF diet, as compared to C-HF diet decreased epididymal hydroperoxides. Feeding sardine protein diets decreased brown adipose tissue carbonyls and increased glutathione peroxidase activity. Perirenal and epididymal superoxide dismutase and catalase activities and brown catalase activity were significantly greater in $\mathrm{S}-\mathrm{HF}$ group than in $\mathrm{C}-\mathrm{HF}$ group. Sardine protein diets also prevented hyperleptinemia and reduced inflammatory status in comparison with rats fed casein diets. Taken together, these results support the beneficial effect of sardine protein in fructose-induced metabolic syndrome on such variables as hyperglycemia, insulin resistance, hyperlipidemia and oxidative
\end{abstract}

Correspondence to: Professor Willy J. Malaisse, Laboratory of Experimental Hormonology, Université Libre de Bruxelles, 808 Route de Lennik, B-1070 Brussels, Belgium

E-mail: malaisse@ulb.ac.be

Key words: metabolic syndrome, fructose, sardine protein, rats and inflammatory status, suggesting the possible use of sardine protein as a protective strategy against insulin resistance and related situations.

\section{Introduction}

The metabolic syndrome (MS) is a cluster of factors known to increase the risk for the development of diabetes mellitus and cardiovascular disease (1). Insulin resistance, hyperleptinemia and low plasma levels of adiponectin are also widely related to features of the MS (2). Metabolic syndrome is a proinflammatory condition (3), and recent studies have suggested that inflammatory mediators such as tumor necrosis factor- $\alpha$ (TNF- $\alpha$ ), interleukins (IL-6) and C-reactive protein (CRP) play a central role in the development of cardiovascular diseases and improve the ability to predict the risk of cardiovascular events and diabetes with occurrence of the metabolic syndrome (4-6). Adipose tissue is considered as dominant sites affecting systemic insulin resistance, and especially visceral adipose tissue plays an important role in metabolic syndrome. Adipose tissue secretes several hormones such as leptin and adiponectin, and a variety of adipocytokines (IL-1 $\beta$, IL-6, IL-8, IL-10, TNF- $\alpha$, TGF- $\beta$ ) which are involved in the development of MS (7).

Animal studies have shown that a high-fructose diet induces well characterized metabolic syndrome resulting in hyperinsulinemia, insulin resistance, hypertension, hypertriglyceridemia, and decreased high-density lipoprotein cholesterol (8). Studies in humans have shown that high fructose diets can result in dyslipidemia, insulin resistance and increased visceral adiposity (9). Moreover, fructose-fed rats display oxidative stress, an imbalance between free radical production and antioxidant defense in several tissues (10).

Dietary recommendations have been proposed in order to prevent or reduce the development of MS in general population. Epidemiological studies have shown that the consumption of fish is associated with a reduced risk of type 2 diabetes (11). This beneficial effect could be due at least in part to reduced inflammation. Indeed, fish consumption has been reported to be independently and inversely associated with circulating levels of several inflammatory markers $(12,13)$. This effect has been attributed to n-3 polyunsaturated fatty acids, such 
as eicosapentaenoic (EPA, C20:5 103 ) and docosahexaenoic acid (DHA, C22:6w3) in fish oil. Moreover, epidemiological studies suggest that another constituent in fish could protect against the development of impaired glucose tolerance and non-insulin-dependent diabetes mellitus in lean fish eaters (11). Few studies have focused on the role of dietary proteins on the regulation of insulin sensitivity and glucose homeostasis. Human studies showed that fish protein, compared with others animal proteins significantly improved insulin sensitivity (14) and lowered hsCRP, a marker of inflammation associated with insulin resistance and type 2 diabetes (15). In rats fed a highsucrose diet, cod and soy proteins were found to reduce fasting plasma glucose concentrations and improve glucose tolerance and whole body insulin action on glucose disposal as compared to casein (16). In our previous study, consumption of sardine protein to streptozotocin-induced type 1 diabetic rats reduced HbA1C, serum glucose and lipids as compared to casein (17). Therefore, the objective of this study was to investigate whether sardine protein (Sardina pilchardus) in comparison with casein influences insulin resistance, lipid profile, leptin and TNF- $\alpha$ levels and protects against the adipose tissue pro-oxidant effect of a high-fructose diet.

\section{Materials and methods}

Preparation of sardine protein. The fish protein prepared in the laboratory and used in this experiment was isolated from sardine's fillets. The heads, internal organs and bones of the sardines were removed, and minced. Then, sardine proteins were purified according to the method of Undeland et al (18). Residual lipid content of fish protein was verified by the Soxhlet method. Crude protein ( $\mathrm{N}$ x 6.25) content of protein preparations was assayed by the Kjeldahl method using a Kjell Foss autoanalyzer. The constituents $(\mathrm{g} / 100 \mathrm{~g})$ of the protein obtained by these operations were $93 \mathrm{~g}$ protein, $0.9 \mathrm{~g}$ lipids, $2.5 \mathrm{~g}$ ashes and $3.6 \mathrm{~g}$ moisture.

Animals, induction of metabolic syndrome, and diets. Weaning male Wistar rats (Iffa Credo, l'Arbresle, France) were housed individually in stainless-steel cages in a temperature $\left(24^{\circ} \mathrm{C}\right)$ and humidity (60\%)-controlled room with a 12 -h cycle of light $(07: 00$ to 19:00) and dark and had free access to a standard commercial rat diet. When their body weights reached 190-200 g, they were randomly divided into four groups of six rats each and were fed for 2 months one of the diets defined in Table I. Two groups were fed control diets containing casein $(\mathrm{C})$ or sardine protein (S) as the protein source and 2 groups were fed a high-fructose (HF) diet containing 64\% fructose (67.19\% of total energy) with casein $(\mathrm{C}-\mathrm{HF})$ or sardine protein $(\mathrm{S}-\mathrm{HF})$ as the protein source. Diets were isoenergetic $(16.28 \mathrm{MJ} / \mathrm{kg})$ and contained identical amounts of lipids, vitamins, minerals and fiber. The body weights of the animals were recorded once a week and food intake was measured daily. This study was carried out in accordance with the general guidelines for the care and use of laboratory animals recommended by the Council of European Communities (19).

Glucose tolerance test. Fifty days after the start of the present experiments, all rats underwent, after overnight starvation, an intraperitoneal glucose tolerance test (IPGTT). For such
Table I. Composition of the experimental diets ${ }^{\mathrm{a}}$.

\begin{tabular}{lcccc}
\hline & \multicolumn{4}{c}{ Groups $^{\mathrm{b}}$} \\
\cline { 2 - 5 } Ingredient & $\mathrm{C}$ & $\mathrm{S}$ & $\mathrm{C}-\mathrm{HF}$ & $\mathrm{S}-\mathrm{HF}$ \\
\hline Casein $^{\mathrm{CC}}{ }^{\mathrm{c}}$ & 200 & - & 200 & - \\
Sardine protein (S) & - & 200 & - & 200 \\
Fructose $^{\mathrm{c}}$ & - & - & 640 & 640 \\
Corn starch $_{\text {Sucrose }}^{590}$ & 590 & - & - \\
Sunflower oil & 50 & 50 & - & - \\
Cellulose $_{\text {Vitamin }^{\mathrm{d}}}$ & 50 & 50 & 50 & 50 \\
Mineral $^{\mathrm{e}}$ & 50 & 50 & 50 & 50 \\
\hline
\end{tabular}

${ }^{\mathrm{a} D i e t s}$ were isoenergetic $(16.28 \mathrm{MJ} / \mathrm{kg}$ of diet $)$ and given in powdered

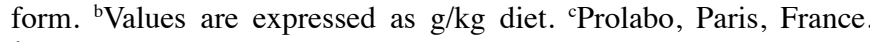
${ }^{\mathrm{d} U A R}$ 200; (Villemoisson), 91360 Epinay/Orge, France. Vitamin mixture provides the following amounts $(\mathrm{mg} / \mathrm{kg}$ diet): retinol, 12; cholecalciferol, 0.125; thiamine, 40; riboflavin, 30; pantothenic acid, 140; pyridoxine, 20; inositol, 300; cyanocobalamin, 0.1; ascorbic acid, 1600; dl- $\alpha$-tocopherol, 340; menadione, 80; nicotinic acid, 200; para-aminobenzoic acid, 100; folic acid, 10; biotin, 0.6. 'UAR 205 B (Villemoisson), 91360 Epinay/Orge, France. The salt mixture provides the following amounts (mg/kg diet): $\mathrm{CaHPO}_{4}, 17200 ; \mathrm{KCl}$, $4000 ; \mathrm{NaCl}, 400 ; \mathrm{MgO}, 420 ; \mathrm{MgSO}_{4}, 2000 ; \mathrm{Fe}_{2} \mathrm{O}_{3}, 120 ; \mathrm{Fe}_{2} \mathrm{SO}_{4} \cdot 7 \mathrm{H}_{2} \mathrm{O}$, 200; trace elements, $400 ; \mathrm{MnSO}_{4} \cdot \mathrm{H}_{2} \mathrm{O}, 98 ; \mathrm{CuSO}_{4} \cdot 5 \mathrm{H}_{2} \mathrm{O}, 20 ; \mathrm{ZnSO}_{4}$, $80 ; \mathrm{CoSO}_{4} .7 \mathrm{H}_{2} \mathrm{O}, 0.16 ; \mathrm{Kl}, 0.32$.

purpose, $1.0 \mathrm{~g} \mathrm{D}$-glucose $/ \mathrm{kg}$ body weight was administered as a 50\% (w/w) D-glucose solution. Tail vein blood samples were collected before (time zero) and 15, 30, 60, 90 and $120 \mathrm{~min}$ after the administration of D-glucose.

Blood and tissue isolation. At the end of the feeding period, after overnight fasting, blood was withdrawn from the abdominal aorta under pentobarbital anesthesia $(60 \mathrm{mg} / \mathrm{kg}$ body weight) in citric acid tubes. Plasma obtained after low speed centrifugation $(3000 \times \mathrm{g}, 15 \mathrm{~min})$ was stored at $-70^{\circ} \mathrm{C}$ for biochemical analysis. Brown, perirenal and epididymal adipose tissues and gastrocnemius muscle were excised, weighed and immediately frozen at $-70^{\circ} \mathrm{C}$ until needed for analysis. The ratio (epididymal fat/gastrocnemius muscle, $\mathrm{g} / \mathrm{g}$ ) was calculated as body composition index and was considered as an index of adiposity (20).

Plasma analysis. Plasma glucose was measured enzymatically (21). Insulin in plasma was measured by radioimmunoassay (22). Homeostasis model assessment-insulin resistance (HOMA-IR) was calculated to measure the insulin sensitivity of the rats fed the experimental diets by the following formula: glycemia $(\mathrm{mmol} / \mathrm{l}) \times$ insulinemia $(\mu \mathrm{U} / \mathrm{ml}) / 22.5$. Glycated haemoglobin (HbA1C) was determined by micro column enzymatic method (Biocon, Diagnostik, Gmbh, Burbach, Germany). Triacylglycerol and calcium concentrations were determined in plasma by enzymatic procedures (kit Spinreact, Spain). Plasma free fatty acids (Wako Chemicals, Neuss, Allemagne) and fibrinogen (Vonclauss, Belgium) levels were measured by 
Table II. Body weight, food intake and adipose tissue relative weights in rats fed sardine protein or casein with or without high fructose diet for 60 days.

\begin{tabular}{|c|c|c|c|c|c|c|c|}
\hline \multirow[b]{2}{*}{ Variables } & \multicolumn{4}{|c|}{ Diets } & \multicolumn{3}{|c|}{ P-value } \\
\hline & $\mathrm{C}$ & $\mathrm{S}$ & C-HF & $\mathrm{S}-\mathrm{HF}$ & Prot & Fru & Prot $\mathrm{x}$ Fru \\
\hline Final body weight (g) & $354.83 \pm 9.92$ & $339.8 \pm 9.14$ & $369.95 \pm 11.40^{\mathrm{b}}$ & $358.92 \pm 10.97^{\mathrm{b}}$ & NS & $\mathrm{P}<0.05$ & NS \\
\hline Food intake (g/d/rat) & $24.45 \pm 2.20$ & $20.11 \pm 1.26^{\mathrm{a}}$ & $18.63 \pm 0.63^{\mathrm{b}}$ & $17.27 \pm 1.15^{\mathrm{a}, \mathrm{b}}$ & $\mathrm{P}<0.05$ & $\mathrm{P}<0.05$ & $\mathrm{P}<0.05$ \\
\hline Index of adiposity & $2.68 \pm 0.14$ & $2.05 \pm 0.29^{\mathrm{a}}$ & $3.16 \pm 0.28^{b}$ & $2.80 \pm 0.35^{\mathrm{a}, \mathrm{b}}$ & $\mathrm{P}<0.05$ & $\mathrm{P}<0.05$ & $\mathrm{P}<0.05$ \\
\hline PAT (g/100 g BW) & $0.75 \pm 0.24$ & $0.72 \pm 0.28$ & $1.10 \pm 0.11^{\mathrm{b}}$ & $1.05 \pm 0.01^{\mathrm{a}, \mathrm{b}}$ & NS & $\mathrm{P}<0.05$ & $\mathrm{P}<0.05$ \\
\hline $\operatorname{EAT}(\mathrm{g} / 100 \mathrm{~g} \mathrm{BW})$ & $1.16 \pm 0.30$ & $0.99 \pm 0.18^{\mathrm{a}}$ & $1.44 \pm 0.16$ & $1.28 \pm 0.13^{\mathrm{a}, \mathrm{b}}$ & $\mathrm{P}<0.05$ & $\mathrm{P}<0.05$ & $\mathrm{P}<0.05$ \\
\hline BAT (g/100 g BW) & $0.19 \pm 0.01$ & $0.20 \pm 0.02$ & $0.21 \pm 0.03$ & $0.21 \pm 0.03$ & NS & NS & NS \\
\hline
\end{tabular}

Data are mean $\pm \mathrm{SD}$ of six rats per group. ${ }^{\mathrm{a}} \mathrm{P}<0.05$, sardine protein versus casein with or without fructose ( $\mathrm{S}$ versus $\mathrm{C}, \mathrm{S}-\mathrm{HF}$ versus $\mathrm{C}-\mathrm{HF}$ ); ${ }^{\mathrm{b}} \mathrm{P}<0.05$, fructose supplementation versus no supplementation (C-HF versus $\mathrm{C}, \mathrm{S}-\mathrm{HF}$ versus $\mathrm{S}$ ); PAT, perirenal adipose tissue; EAT, epididymal adipose tissue; BAT, brown adipose tissue; BW, body weight; Index of adiposity = epididymal fat/gastrocnemius muscle, $\mathrm{g} / \mathrm{g}$.

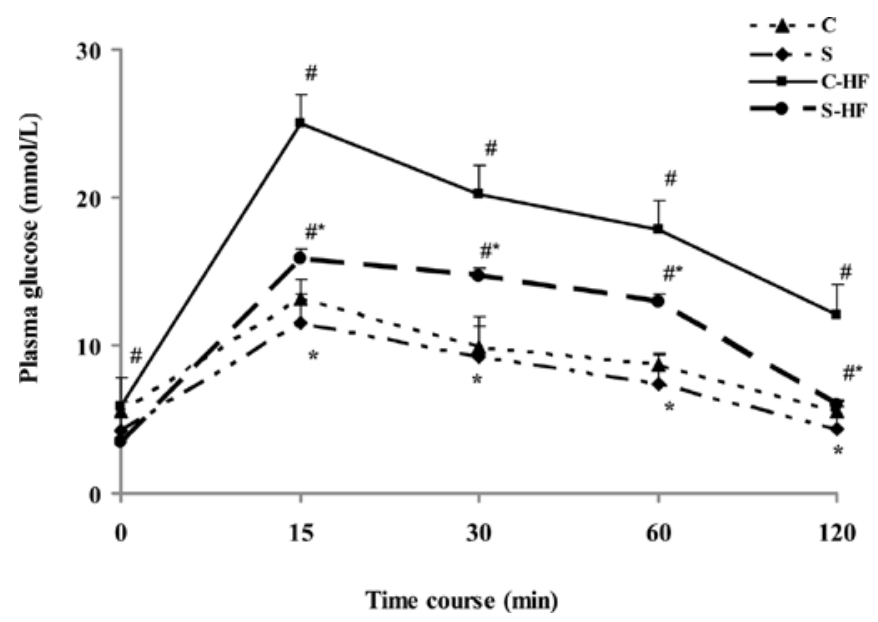

Figure 1. Plasma glucose response to IPGTT in rats fed sardine protein or casein with or without high fructose diets for 60 days. Mean values $( \pm$ SD) refer to 6 rats in each group. ${ }^{*} \mathrm{P}<0.05$, sardine protein versus casein with or without fructose (S versus $\mathrm{C}, \mathrm{S}-\mathrm{HF}$ versus $\mathrm{C}-\mathrm{HF}$ ); ${ }^{\#} \mathrm{P}<0.05$, fructose supplementation versus no supplementation (C-HF versus $\mathrm{C}, \mathrm{S}-\mathrm{HF}$ versus $\mathrm{S}$ ).

enzymatic method. Plasma leptin concentrations were measured by radioimmunoassay by use of a rat leptin-specific kit from Assay Designs Inc. (MI, USA). Enzyme-linked immunosorbent assays (ELISA) were used for the detection of tumor necrosis factor- $\alpha$ (TNF- $\alpha$ ) in plasma (Quantikine Mouse TNF- $\alpha$ Immunoassay, R\&D Systems Europe, Abingdon, UK). Plasma $\alpha$-tocopherol was assayed (23). Ascorbic acid in plasma was determined by HPLC method. Plasma taurine levels were determined by reverse-phase HPLC (Beckman Coulter, Canada).

Adipose tissue analysis. Lipid and protein oxidation. For lipid peroxidation studies of adipose tissue, homogenates were prepared on ice in a ratio of $1 \mathrm{~g}$ wet perirenal and epididymal white and brown adipose tissues to $9 \mathrm{ml} 150 \mathrm{mmol} / \mathrm{l} \mathrm{KCl}$ using ultraturrax homogenizer. Thiobarbituric acid-reactive substances (TBARS) were measured (24). Hydroperoxide levels in adipose tissue were evaluated (25). Brown adipose tissue carbonyl concentrations were determined (26).
Antioxidant enzymes. Catalase (CAT, EC, 1.11.1.6) activity was measured in perirenal and epididymal white and brown adipose tissues (27). Superoxide dismutase (SOD, EC 1.15.1.1) activity was measured by the NADH oxidation procedure (Cayman Chemical kit, USA). Glutathione peroxidase (GSH-Px, EC 1.11.1.9) was assayed using commercial kit (Cayman Chemical kit).

Statistical analysis. Values are means \pm SD of six rats per group. Statistical analysis was performed using the Statistica 6 (Statsoft, Tulsa, OK). Data were tested using two-way ANOVA with type of protein and fructose content as independent variables. When the interaction was significant, Fischer's least significant difference test was performed. A difference of $\mathrm{P} \leq 0.05$ was considered significant.

\section{Results}

Food intake and body and adipose tissue weight. Although there was no significant difference in body weight between dietary protein groups at the end of a 60-day period, the total food intake was significantly lower with S and S-HF diets compared to $\mathrm{C}$ and $\mathrm{C}-\mathrm{HF}$ diets. Feeding the HF diets resulted in high body weights but low food intake as compared to control diets. The epididymal wet weight and body composition index were significantly decreased in rats that received $\mathrm{S}$ and $\mathrm{S}-\mathrm{HF}$ diets, when compared to those receiving $\mathrm{C}$ and $\mathrm{C}-\mathrm{HF}$ diets. Perirenal adipose tissue wet weight was lower in S-HF rats than in $\mathrm{C}-\mathrm{HF}$ rats. Addition of fructose to both protein diets increased perirenal fat and adiposity. Furthermore, epididymal adipose tissue weight decreased significantly when rats were fed the HF diet in combination with S, but not with $\mathrm{C}$ (Table II). Fructose treatment did not affect brown adipose tissue wet weight.

Glucose tolerance test. The results of the glucose tolerance test in experimental animals are depicted in Fig. 1. Compared with casein, the sardine protein diet (with or without fructose) significantly decreased the plasma glucose concentrations at all time points. Incorporation of fructose in both protein diets 
Table III. Plasma metabolic and hormonal data in rats fed sardine protein or casein with or without high fructose in the diet for 60 days.

\begin{tabular}{|c|c|c|c|c|c|c|c|}
\hline \multirow[b]{2}{*}{ Variables } & \multicolumn{4}{|c|}{ Diets } & \multicolumn{3}{|c|}{ P-value } \\
\hline & $\mathrm{C}$ & $S$ & $\mathrm{C}-\mathrm{HF}$ & S-HF & Prot & Fru & Prot $x$ Fru \\
\hline Glucose $(\mathrm{mmol} / \mathrm{l})$ & $5.96 \pm 0.30$ & $5.11 \pm 0.42$ & $8.31 \pm 1.06^{\mathrm{b}}$ & $6.54 \pm 0.47^{\mathrm{a}, \mathrm{b}}$ & NS & $\mathrm{P}<0.05$ & $\mathrm{P}<0.05$ \\
\hline Insulin $(\mu \mathrm{U} / \mathrm{ml})$ & $53.59 \pm 2.62$ & $32.98 \pm 8.33^{\mathrm{a}}$ & $66.65 \pm 5.97$ & $43.22 \pm 12.25^{\mathrm{a}, \mathrm{b}}$ & $\mathrm{P}<0.05$ & $\mathrm{P}<0.05$ & $\mathrm{P}<0.05$ \\
\hline HOMA-IR & $14.88 \pm 7.51$ & $7.74 \pm 2.31^{\mathrm{a}}$ & $21.94 \pm 5.43^{\mathrm{b}}$ & $12.70 \pm 4.46^{\mathrm{a}, \mathrm{b}}$ & $\mathrm{P}<0.05$ & $\mathrm{P}<0.05$ & $\mathrm{P}<0.05$ \\
\hline $\mathrm{HbA} 1 \mathrm{C} \%$ & $6.74 \pm 0.74$ & $5.65 \pm 0.38$ & $16.42 \pm 1.74^{\mathrm{b}}$ & $10.39 \pm 1.29^{\mathrm{a}, \mathrm{b}}$ & NS & $\mathrm{P}<0.05$ & $\mathrm{P}<0.05$ \\
\hline Triacylglycerol (mmol/l) & $1.21 \pm 0.08$ & $0.92 \pm 0.09^{\mathrm{a}}$ & $3.86 \pm 1.15^{\mathrm{b}}$ & $2.04 \pm 1.23^{\mathrm{a}, \mathrm{b}}$ & $\mathrm{P}<0.05$ & $\mathrm{P}<0.05$ & $\mathrm{P}<0.05$ \\
\hline Free fatty acids (mmol/l) & $0.40 \pm 0.06$ & $0.26 \pm 0.06^{\mathrm{a}}$ & $1.08 \pm 0.06^{\mathrm{b}}$ & $0.79 \pm 0.10^{\mathrm{a}, \mathrm{b}}$ & $\mathrm{P}<0.05$ & $\mathrm{P}<0.05$ & $\mathrm{P}<0.05$ \\
\hline$\alpha$-tocopherol $(\mu \mathrm{mol} / \mathrm{l})$ & $33.66 \pm 4.34$ & $41.66 \pm 5.00^{\mathrm{a}}$ & $22 \pm 4.69^{\mathrm{b}}$ & $27.50 \pm 4.59^{\mathrm{b}}$ & $\mathrm{P}<0.05$ & $\mathrm{P}<0.05$ & NS \\
\hline Ascorbic acid $(\mu \mathrm{mol} / \mathrm{l})$ & $53 \pm 1.41$ & $63.33 \pm 8.06$ & $30.50 \pm 4.41$ & $41.83 \pm 4.83$ & NS & NS & NS \\
\hline Taurine $(\mu \mathrm{mol} / \mathrm{l})$ & $206 \pm 4.73$ & $213 \pm 6.74^{\mathrm{a}}$ & $113 \pm 2.99^{b}$ & $124.33 \pm 4.27^{\mathrm{a}, \mathrm{b}}$ & $\mathrm{P}<0.05$ & $\mathrm{P}<0.05$ & $\mathrm{P}<0.05$ \\
\hline Calcium (mmol/l) & $1.63 \pm 0.08$ & $2.02 \pm 0.10^{\mathrm{a}}$ & $1.31 \pm 0.01^{\mathrm{b}}$ & $1.45 \pm 0.18^{\mathrm{a}, \mathrm{b}}$ & $\mathrm{P}<0.05$ & $\mathrm{P}<0.05$ & $\mathrm{P}<0.05$ \\
\hline Fibrinogen (g/l) & $1.70 \pm 0.17$ & $1.49 \pm 0.13^{\mathrm{a}}$ & $2.14 \pm 0.16^{\mathrm{b}}$ & $1.92 \pm 0.31^{\mathrm{b}}$ & $\mathrm{P}<0.05$ & $\mathrm{P}<0.05$ & NS \\
\hline
\end{tabular}

Data are mean $\pm \mathrm{SD}$ of six rats per group; ${ }^{\mathrm{a}} \mathrm{P}<0.05$, sardine protein versus casein with or without fructose ( $\mathrm{S}$ versus $\mathrm{C}, \mathrm{S}-\mathrm{HF}$ versus $\mathrm{C}-\mathrm{HF}$ ). ${ }^{\mathrm{b}} \mathrm{P}<0.05$, fructose supplementation versus no supplementation (C-HF versus $\mathrm{C}, \mathrm{S}-\mathrm{HF}$ versus $\left.\mathrm{S}\right)$; HOMA-IR $=$ glycemia $(\mathrm{mmol} / \mathrm{l}) \mathrm{x}$ insulinemia $(\mu \mathrm{U} / \mathrm{ml}) / 22.5$.

Table IV. Levels of TBARS, lipid hydroperoxide and carbonyl in adipose tissues in rats fed sardine protein or casein with or without high fructose in the diet for 60 days.

\begin{tabular}{|c|c|c|c|c|c|c|c|}
\hline \multirow[b]{2}{*}{ Variables } & \multicolumn{4}{|c|}{ Diets } & \multicolumn{3}{|c|}{ P-value } \\
\hline & $\mathrm{C}$ & $S$ & $\mathrm{C}-\mathrm{HF}$ & $\mathrm{S}-\mathrm{HF}$ & Prot & Fru & Prot $x$ Fru \\
\hline \multicolumn{8}{|l|}{ Perirenal } \\
\hline TBARS $(\mu \mathrm{mol} / \mathrm{g})$ & $0.84 \pm 0.04$ & $0.82 \pm 0.03$ & $0.95 \pm 0.04^{\mathrm{b}}$ & $0.92 \pm 0.01^{\mathrm{b}}$ & NS & $\mathrm{P}<0.05$ & NS \\
\hline Hydroperoxides $(\mu \mathrm{mol} / \mathrm{g})$ & $2.44 \pm 0.49$ & $1.54 \pm 0.71^{\mathrm{a}}$ & $6.24 \pm 2.60^{\mathrm{b}}$ & $4.65 \pm 1.29^{\mathrm{a}, \mathrm{b}}$ & $\mathrm{P}<0.05$ & $\mathrm{P}<0.05$ & $\mathrm{P}<0.05$ \\
\hline \multicolumn{8}{|l|}{ Epididymal } \\
\hline TBARS $(\mu \mathrm{mol} / \mathrm{g})$ & $0.66 \pm 0.09$ & $0.61 \pm 0.10$ & $0.87 \pm 0.06^{b}$ & $0.89 \pm 0.05^{\mathrm{b}}$ & NS & $\mathrm{P}<0.05$ & NS \\
\hline Hydroperoxides $(\mu \mathrm{mol} / \mathrm{g})$ & $1.74 \pm 0.56$ & $1.54 \pm 0.67$ & $3.92 \pm 1.12^{\mathrm{b}}$ & $2.63 \pm 0.75^{\mathrm{a}, \mathrm{b}}$ & NS & NS & $\mathrm{P}<0.05$ \\
\hline \multicolumn{8}{|l|}{ Brown } \\
\hline TBARS $(\mu \mathrm{mol} / \mathrm{g})$ & $0.47 \pm 0.15$ & $0.50 \pm 0.32$ & $1.21 \pm 0.13^{\mathrm{b}}$ & $0.73 \pm 0.17^{\mathrm{a}, \mathrm{b}}$ & NS & $\mathrm{P}<0.05$ & $\mathrm{P}<0.05$ \\
\hline Hydroperoxides $(\mu \mathrm{mol} / \mathrm{g})$ & $2.02 \pm 0.11$ & $1.23 \pm 0.31^{\mathrm{a}}$ & $2.65 \pm 0.31^{\mathrm{b}}$ & $2.26 \pm 0.14^{\mathrm{a}, \mathrm{b}}$ & $\mathrm{P}<0.05$ & $\mathrm{P}<0.05$ & $\mathrm{P}<0.05$ \\
\hline Carbonyls (nmol/g) & $108.88 \pm 27.11$ & $90.09 \pm 5.94^{\mathrm{a}}$ & $171.68 \pm 23.78^{\mathrm{b}}$ & $140.41 \pm 11.75^{\mathrm{a}, \mathrm{b}}$ & $\mathrm{P}<0.05$ & $\mathrm{P}<0.05$ & $\mathrm{P}<0.05$ \\
\hline
\end{tabular}

Data are mean $\pm \mathrm{SD}$ of six rats per group. ${ }^{\mathrm{a}} \mathrm{P}<0.05$, sardine protein versus casein with or without fructose ( $\mathrm{S}$ versus $\mathrm{C}, \mathrm{S}-\mathrm{HF}$ versus $\mathrm{C}-\mathrm{HF}$ ); ${ }^{\mathrm{b}} \mathrm{P}<0.05$, fructose supplementation versus no supplementation (C-HF versus C, S-HF versus $\mathrm{S}$ ).

induced significant elevations $(\mathrm{P}<0.05)$ in the glucose level at all time points as compared to that in the control rats.

Metabolic and hormonal data of control and experimental groups. Fructose-free sardine protein versus casein consumption decreased significantly plasma insulin, triacylglycerol, free fatty acids, fibrinogen, and HOMA-IR and enhanced plasma $\alpha$-tocopherol, taurine and calcium at 8 weeks of experiment (Table III).

Plasma glucose and insulin levels were significantly lower in the S-HF group than that recorded in the C-HF group.
HOMA-IR index and HbA1C were reduced in the S-HF rats as compared to the $\mathrm{C}$-HF rats. Plasma triacylglycerol and free fatty acids concentrations were significantly reduced in S-HF than in C-HF. Plasma taurine and calcium levels were significantly higher in the S-HF than those found in C-HF animals.

Rats fed the HF diets had significantly higher plasma glucose, triacylglycerols, free fatty acids, fibrinogen, HOMA-IR and $\mathrm{HbA} 1 \mathrm{C}$ and lower plasma $\alpha$-tocopherol, taurine and calcium than those fed the control diets (Table III). Only rats fed the $\mathrm{S}-\mathrm{HF}$ diet showed hyperinsulinemia as compared to control diet. 

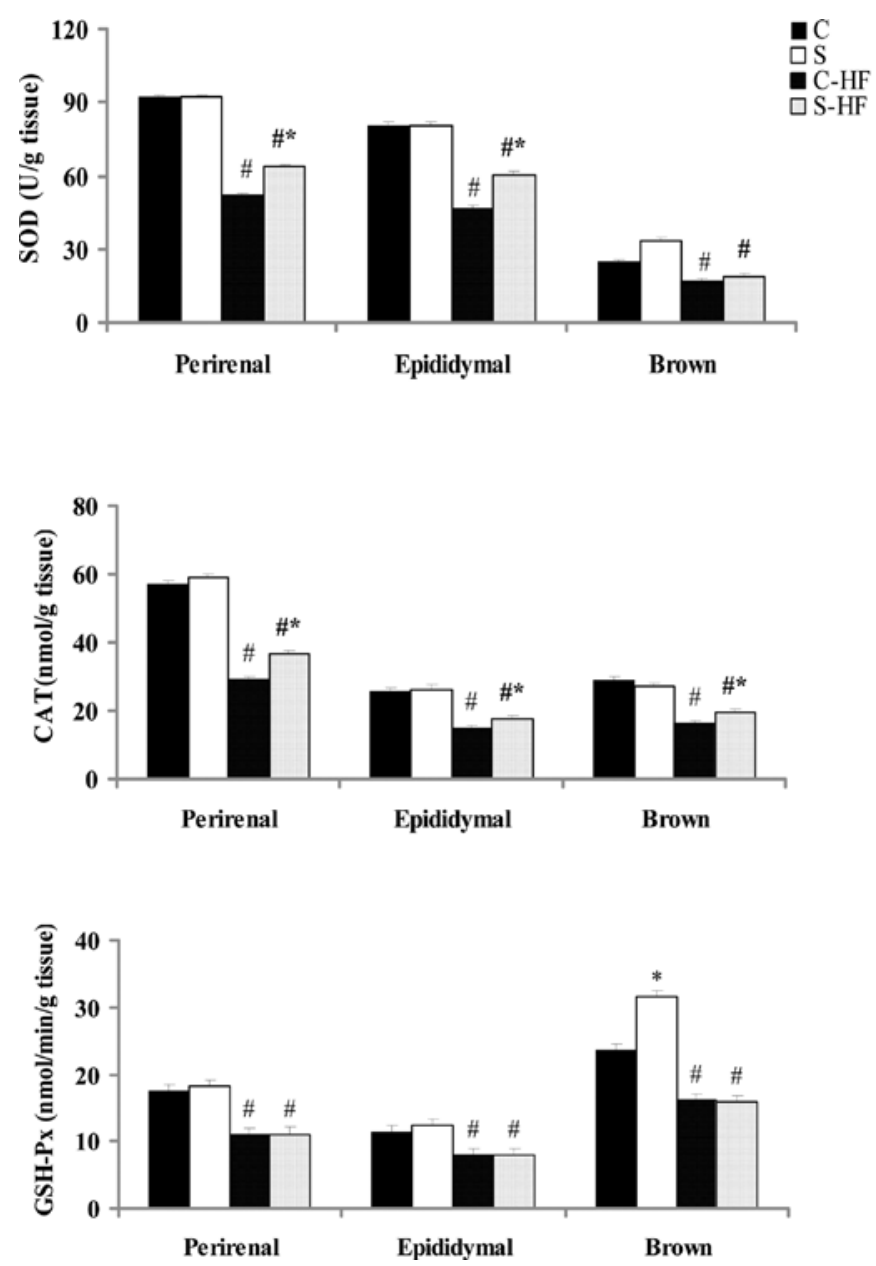

Figure 2. Adipose tissue antioxidant enzyme activities in rats fed sardine protein or casein with or without high fructose diet for 60 days. Means values $\left( \pm\right.$ SD) refer to 6 rats in each group. ${ }^{*} \mathrm{P}<0.05$, sardine protein versus casein with or without fructose (S versus $\mathrm{C}, \mathrm{S}-\mathrm{HF}$ versus $\mathrm{C}-\mathrm{HF}$ ); ${ }^{\text {"}} \mathrm{P}<0.05$, fructose supplementation versus no supplementation (C-HF versus $\mathrm{C}, \mathrm{S}-\mathrm{HF}$ versus $\mathrm{S}$ ).

Lipid and protein oxidation. Perirenal and brown adipose tissues hydroperoxide levels were significantly lower in rats fed $\mathrm{S}$ and $\mathrm{S}-\mathrm{HF}$ than in those fed $\mathrm{C}$ and $\mathrm{C}-\mathrm{HF}$ diets (Table IV). TBARS concentrations in brown adipose tissue were significantly lower in S-HF-fed rats as compared to C-HF rats (Table IV).

TBARS and hydroperoxide concentrations of all adipose tissues were greater in HF diets compared to control diets. Furthermore, carbonyls contents were enhanced in brown adipose tissue of HF rats.

Antioxidant enzyme activities. The activities of antioxidant enzymes (SOD, CAT and GSH-Px) in the adipose tissues of experimental and control rats are presented in Fig. 2. Fructosefree sardine protein rats increased GSH-Px activity in brown adipose tissue relative to $C$ rats. Feeding sardine protein diet in fructose group led to increased eipdidymal and perirenal white adipose tissues SOD activity by about $30 \%$ and $23 \%$ relative to C-HF group, whereas, brown adipose tissue SOD activity was unaffected by changes in dietary proteins. Moreover, S-HF animals presented higher CAT activity in perirenal (26\%), epididymal (20\%) and brown (21\%) adipose tissues than C-HF rats. No significant difference was observed between the two
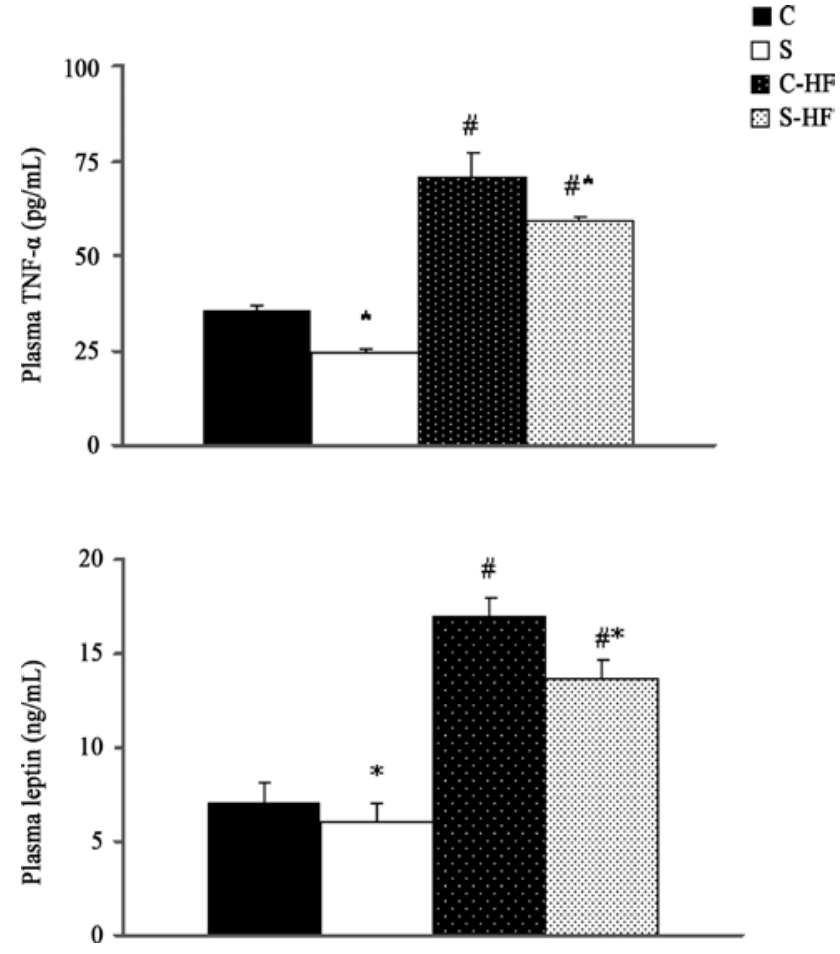

Figure 3. Plasma leptin and tumor necrosis factor (TNF- $\alpha$ ) concentrations in rats fed sardine protein or casein with or without high fructose diet for 60 days. Mean values $\left( \pm \mathrm{SD}\right.$ ) refer to 6 rats in each group. ${ }^{*} \mathrm{P}<0.05$, sardine protein versus casein with or without fructose (S versus $\mathrm{C}, \mathrm{S}-\mathrm{HF}$ versus $\mathrm{C}-\mathrm{HF}$ ); ${ }^{\text {}} \mathrm{P}<0.05$, fructose supplementation versus no supplementation (C-HF versus $\mathrm{C}, \mathrm{S}-\mathrm{HF}$ versus $\mathrm{S}$ ).

fructose groups in respect to GSH-Px activity. Addition of fructose to both protein diets decreased significantly SOD, CAT and GSH-Px activities in perirenal and epididymal white and brown adipose tissues in comparison with control rats (Fig. 2).

Plasma cytokine levels. Fructose-free sardine protein as compared to casein feeding lowered plasma leptin $(15 \%)$ and TNF- $\alpha$ (31\%) concentrations (Fig. 3). The S-HF diet, as compared to C-HF diet, also reduced plasma TNF- $\alpha$ (16\%) and leptin (19\%) levels. Feeding HF diets resulted in greater plasma leptin and TNF- $\alpha$ concentrations compared with those found in rats fed the control diets.

\section{Discussion}

It is clearly established that chronic high-fructose consumption is associated with the development of metabolic syndrome $(28,29)$. However, dietary protein type can have a significant influence on insulin action and glucose homeostasis, as demonstrated in this study.

Rats on the high fructose diets ate less than controls but gained more weight and body fat, suggesting that high fructose feeding may suppress food intake in the long term or decrease energy expenditure or has satiating effect. Additionally, highfructose diet led to increased adiposity. Similar results were observed by Moran (30). Despite lower food intake and adipose tissue fat weights in rats consuming $\mathrm{S}$ and S-HF diets, the body weight during the 60 day feeding was virtually identical in the 4 
groups of rats. Adiposity was significantly lower, however, in $\mathrm{S}$ and $\mathrm{S}-\mathrm{HF}$ groups than in $\mathrm{C}$ and $\mathrm{C}-\mathrm{HF}$ groups.

The addition of fructose to both protein diets enhanced HbA1C, plasma glucose and insulin levels and insulin resistance. Insulin resistance may occur due to a defect in insulin binding caused by decreased receptor number or affinity, or defects at the level of effector molecules such as glucose transporters and enzymes involved in glucose metabolism (31-33). Rats assigned to the S and S-HF diets displayed a significant reduction in the glucose response to IPGTT compared to rats following the $\mathrm{C}$ and $\mathrm{C}-\mathrm{HF}$ diets. Similar to our results, Lavigne et al (16) found that, in rats fed a high-sucrose diet, cod and soy proteins were found to reduce fasting plasma glucose concentrations and improve glucose tolerance and whole body insulin action on glucose disposal as compared to casein. After 60 days of consumption, S-HF group had a $21 \%$ decrease in plasma glucose compared to $\mathrm{C}-\mathrm{HF}$ group suggesting protection of $\mathrm{S}-\mathrm{HF}$ against hyperglycemia $(\mathrm{P}<0.05)$. Mellouk et al $(17)$ reported significant decrease in serum glucose and HbA1C in streptozotocin diabetic rats fed sardine protein as compared to those fed casein. Furthermore, rats fed sardine protein with or without fructose had lower plasma insulin level and displayed decreased insulin resistance, suggesting that dietary proteins can also have a significant influence on insulin action. The observation of improved insulin sensitivity with fish proteins has been previously reported in rats $(16,34)$ and in insulin-resistant men and women (14). The improvement of insulin sensitivity with sardine protein consumption could be related to lower fat deposition. Therefore, it is proposed that fish proteins improve insulin sensitivity by enhancing peripheral insulin sensitivity (16) and normalization of PI 3-kinase/Akt activation coupled to an increased translocation of GLUT4 to the T-tubules (35) as well as by decreasing pancreatic insulin release or increasing hepatic insulin extraction (16). On the other hand, amino acid composition of proteins may also be relevant to account for the effects on insulin resistance (36). Previously, it was shown that taurine normalizes glucose metabolism and attenuates hyperinsulinemia in high fructose-fed rats (10). In our study, consumption of sardine protein diet with or without fructose enhanced plasma taurine levels, when compared to casein-fed rats. Since sardines are a much richer source of taurine (37), this may also explain why the sardine protein rats displayed lower glucose, insulin and insulin resistance than the casein-fed rats.

The results of the current investigation also revealed that high fructose feeding significantly increased the level of triglycerides and free fatty acids. Fructose is a highly lipogenic nutrient which results in increasing cholesterol, triglycerides and fatty acids in blood and liver (38). Excessive FFA delivery to muscle from the circulation can be a source of muscle TG accumulation. The unregulated fructose metabolism generates both glycerol and acyl portions of acyl-glycerol molecules, the substrates for TG synthesis. Increase in acyl CoA carboxylase and diacylglycerol transporter activities has been reported in liver of the fructose-fed hamster (39). Another interesting effect of sardine protein diet in comparison to casein diet with or without fructose is to decrease plasma triacylglycerol. After 2 months of feeding, rats fed S and S-HF diets had 76\% and $53 \%$ lower plasma triacylglycerol in comparison to $\mathrm{C}$ and $\mathrm{C}-\mathrm{HF}$ diets, respectively. These observations could possibly be due to decreased triacylglycerol-rich lipoproteins (VLDL), reduced synthesis of triacylglycerol in the liver, increased catabolism of fatty acids or a diminished secretion of triacylglycerol from the liver via VLDL. It is therefore possible that the reduction in plasma triglycerides was the cause or the result of improved insulin action in sardine protein-fed rats. These results are in agreement with those of recent studies $(16,40)$.

Supplementation of both protein diets with fructose led to adipose tissue oxidative stress, manifested by increased levels of TBARS, lipid hydroperoxide and protein carbonyl. Enhanced lipid peroxidation in HF-fed rats could be associated with high circulating glucose, which enhances free radical production from glucose autoxidation and protein glycation. The increase in tissues lipid peroxides could also have resulted from depletion in cellular, non-enzymatic and enzymatic antioxidant potential in fructose-fed rats. It can be hypothesized that the reasons for decrease in tissue antioxidant enzyme activities would be that increased levels of $\mathrm{O}_{2}^{-}$inactivate CAT and GSH-Px; inactivation of CAT and GSH-Px would lead to an enhancement of $\mathrm{H}_{2} \mathrm{O}_{2}$ level which in turn would inactivate SOD. An increase in the protein carbonyl content in fructose-fed rats suggests protein modification by oxidation. Consumption of sardine protein diet in comparison with casein decreased lipid peroxidation and increased antioxidative defense status. Intake of $\mathrm{S}$ and S-HF diets produced lower perirenal and brown adipose tissues hydroperoxides. Moreover, the S-HF diet, as compared to $\mathrm{C}-\mathrm{HF}$, yielded reduced epididymal hydroperoxide and brown adipose tissue TBARS levels. Taken together, these results suggest that the decrease in glycemia, insulinemia and triglyceridemia produced by sardine protein consumption can be related to decreased lipid peroxide levels. On the other hand, the enhanced ability to detoxify $\mathrm{O}_{2}{ }^{-}$and $\mathrm{H}_{2} \mathrm{O}_{2}$ via $\mathrm{SOD}$ and CAT activities in these tissues appears to be responsible to the decreased lipid peroxidation. Additionally, the observed effects of sardine protein could also be attributed to increasing antioxidant molecules such as $\alpha$-tocopherol which would make the cells less susceptible to the consequence of oxidative stress.

The present study showed that plasma leptin concentrations decreased with decreasing food intake and fat mass but not body weight gain in rats fed $\mathrm{S}$ and $\mathrm{S}$-HF diets as compared to $\mathrm{C}$ and $\mathrm{C}-\mathrm{HF}$ diets. Thus, body fat is an important determinant of plasma leptin level rather than body weight gain. Moreover, a role for glucose transport and/or metabolism in regulating leptin secretion may be considered because fish protein feeding was found to increase glucose transport proteins (Glut-4) (35). Therefore, the ingestion of sardine protein might contribute to the reduction of leptin levels and adiposity, which improves insulin resistance and hyperinsulinemia. Our data do not support the results of Lavigne et al (35) who found similar plasma leptin in obese rats fed cod protein than in those fed casein.

Generally, increased adiposity is a cause for elevated inflammation and fructose intake leads to elevated free fatty acids which further leads to elevated inflammation (41-43). FFAs directly activate macrophages to secrete pro-inflammatory cytokines that render muscle cells insulin resistance (44). The results of this investigation also revealed that fructose treatment significantly increased plasma TNF- $\alpha$ and fibrinogen, together with an increase in body weight, plasma free fatty acid levels and adipose tissue accumulation. Our findings are consistent with previous studies demonstrating that MS is associated with increased inflammatory burden (45). We found a protective effect 
of sardine protein diet with or without fructose against TNF- $\alpha$, a proinflammatory cytokine that has been recognized as a key molecule linking obesity with insulin resistance (46). Several studies have reported a strong inverse relationship between fish consumption and levels of inflammatory markers $(12,13)$. Taken together, these findings suggest that this decrease in inflammation may have an important role in the effect of sardine protein, improving insulin resistance and glucose tolerance in free and high fructose rats. The expression levels of tumor necrosis factor $\alpha$ had a tendency to be lower after the addition of fish protein hydrolysate (47). Our results are inconsistent with those of Lavigne et al (34) who observed similar adipose tissue and skeletal muscle TNF- $\alpha$ concentrations in obese rats fed cod protein as compared to casein.

In conclusion, 2 months of sardine protein feeding induced a marked improvement in glucose tolerance; a reduction in insulin resistance; a reduction in TNF- $\alpha$, leptin and FFA, accompanied by reduction in adiposity and an improvement of oxidative stress in adipose tissues. We therefore suggest that sardine protein presents beneficial effects for the treatment of insulin resistance and type 2 diabetes induced by a high fructose diet. The present study does not allow identification of the constituents responsible for the beneficial effects of sardine protein and future studies are required to compare the effects of distinct amino acids or peptides.

\section{Acknowledgements}

We are grateful to C. Demesmaeker for secretarial help.

\section{References}

1. Wong ND: Metabolic syndrome: cardiovascular risk assessment and management. Am J Cardiovasc Drugs 7: 259-272, 2007.

2. Aquilera CM, Gil-Lampos M, Canete R and Gil A: Alterations in plasma and tissue lipids associated with obesity and metabolic syndrome. Clin Sci 114: 183-193, 2008.

3. Expert Panel on Detection, Evaluation, and Treatment of High Blood Cholesterol in Adults: Executive Summary of the Third Report of the National Cholesterol Education Program (NCEP) Expert Panel on Detection, Evaluation, and Treatment of High Blood Cholesterol in Adults (Adult Treatment Panel III). JAMA 285: 2486-2497, 2001.

4. Pradhan AD, Manson JE, Rifai N, Buring JE and Ridker PM: C-reactive protein, interleukin 6 , and risk of developing type 2 diabetes mellitus. JAMA 286: 327-334, 2001.

5. Winkler G, Kiss S, Keszthelyi L, Sapi Z, Salamon F, Kovacs M, Vargha P, Szekeres O, Speer G, Karadi I, Sikter M, Kaszas E, Dworak O, Gero G and Cseh K: Expression of tumor necrosis factor (TNF)- $\alpha$ protein in the subcutaneous and visceral adipose tissue in correlation with adipocyte cell volume, serum TNF- $\alpha$, soluble serum TNF-receptor-2 concentrations and C-peptide level. Eur J Endocrinol 49: 129-135, 2003.

6. Ridker PM, Wilson PWF and Grundy SM: Should C-reactive protein be added to metabolic syndrome and to assessment of global cardiovascular risk? Circulation 109: 2818-2825, 2004.

7. Ailhaud G: Adipose tissue s a secretory organ: from adipogenesis to the metabolic syndrome. CR Biol 329: 570-577, 2006.

8. Yokozawa T, Kim HJ and Cho EJ: Gravinol ameliorates highfructose-induced metabolic syndrome through regulation of lipid metabolism and proinflammatory state in rat. J Agric Food Chem 56: 5026-5032, 2008.

9. Stanhope KL and Havel PJ: Fructose consumption: potential mechanisms for its effects to increase visceral adiposity and induce dyslipidemia and insulin resistance. Curr Opin Lipidol 19: $16-24,2008$

10. Nandhini AT and Anuradha CV: Taurine modulates kallikrein activity and glucose metabolism in insulin resistant rats. Amino Acids 22: 27-38, 2002.
11. Feskens EJ, Bowles $\mathrm{CH}$ and Kromhout D: Inverse association between fish intake and risk of glucose intolerance in normoglycemic elderly men and women. Diabetes Care 14: 935-941, 1991.

12. Zampelas A, Panagiotakos DB, Pitsavos C, Das UN, Chrysohoou C, Skoumas Y and Stefanadis C: Fish consumption among healthy adults is associated with decreased levels of inflammatory markers related to cardiovascular disease: the ATTICA study. J Am Coll Cardiol 46: 120-124, 2005.

13. Nakamura Y, Ueno Y, Tamaki S, Kadowaki T, Okamura T, Kita Y, Miyamatsu N, Sekikawa A, Takamiya T, El-Saed A, Sutton-Tyrrell $\mathrm{K}$ and Ueshima H: Fish consumption and early atherosclerosis in middle-aged men. Metabolism 56: 1060-1064, 2007.

14. Ouellet V, Marois J, Weisnagel SJ and Jacques H: Dietary cod protein improves insulin sensitivity in insulin-resistant men and women: a randomized controlled trial. Diabetes Care 30: 2816-2821, 2007.

15. Ouellet V, Weisnagel SJ, Marois J, Bergeron J, Julien P, Gougeon R, Tchernof A, Holub BJ and Jacques H: Dietary cod protein reduces plasma C-reactive protein in insulin-resistant men and women. J Nutr 138: 2386-2391, 2008

16. Lavigne C, Marette A and Jacques H: Cod and soy proteins compared with casein improve glucose tolerance and insulin sensitivity in rats. Am J Physiol Endocrinol Metab 278: E491-E500, 2000.

17. Mellouk Z, Ait Yahia D, Boukortt FO, Benaicha N, Madani Z and Bouchenak M: Dietary sardine (Sardina pilchardus) protein attenuates hyperglycemia and hyperlipidemia and ameliorates tissue morphology changes in streptozotocin-induced diabetic rats. Met Funct Res Diab 2: 45-54, 2009.

18. Undeland I, Kelleher SD and Hultin HO: Recovery of functional proteins from herring (Clupea harengus) light muscle by an acid or alkaline solubilization process. J Agric Food Chem 50: 7371-7379, 2002

19. Council of European Communities. Council instructions about the protection of living animals used in scientific investigations. Official J. L358 of 18-12-1986; Corrigendum Official J. L117 of 05-05-1987.

20. Naderali EK and Williams G: Prolonged endothelial-dependent and -independent arterial dysfunction induced in the rat by shortterm feeding with a high-fat, high-sucrose diet. Atherosclerois 166: 253-259, 2003.

21. Bergmeyer HU, Berndt E, Schmidt F and Stork H: D-glucose determination with hexokinase and glucose 6-phosphate dehydrogenase. In: Methods of Enzymatic Analysis. Bergmeyer HU (ed). Vol 3. Academic Press, New York, pp1190-1201, 1974.

22. Leclercq-Meyer V, Marchand J, Woussen-Colle MC, Giroix MH and Malaisse WJ: Multiple effects of leucine on glucagon, insulin, and somatostatin secretion from the perfused rat pancreas. Endocrinology 116: 1168-1174, 1985.

23. Baker H, Frank O, De Angelis B and Feingold S: Plasma tocopherol in man at various times after ingesting free or acetylated tocopherol. Nutr Rep Int 21: 531-536, 1980.

24. Quintanilha AT, Packer L, Szyszio DJM, Racanelly TL and Davies KJA: Membrane effects of vitamin E deficiency bioenergetic and surface charge density studies of skeletal muscle and liver mitochondria. Ann NY Acad Sci 393: 32-47, 1982.

25. Eymand S and Genot C: A modified xylenol orange method to evaluate formation of lipid hydroperoxides during storage and processing of small pelagic fish. Eur J Lipid Sci Technol 105: 497-501, 2003.

26. Levine RL, Garland D, Oliver CN, Amici A, Clement I, Lenz AG, Ahn BW and Shaltiel S: Determination of carbonyl content in oxidatively modified proteins. Methods Enzymol 186: 464-478, 1990.

27. Aebi H: Catalase. In: Methods of Enzymatic Analysis. Bergmeyer HU (ed). 2nd edition. Verlag Chemie Weinheim, pp673-684, 1974.

28. Lê KA and Tappy L: Metabolic effects of fructose. Currt Opin Clin Nutr Metab Care 9: 469-475, 2006.

29. Tappy L and Lê KA: Metabolic effects of fructose and the worldwide increase in obesity. Physiol Rev 90: 23-46, 2010.

30. Moran TH: Fructose and satiety. J Nutr 139: S1243S-S1256, 2009.

31. Kim JK, Gavrilova O, Chen Y, Reitman ML and Shulman GI: Mechanism of insulin resistance in A-ZIP/F-1 fatless mice. J Biol Chem 275: 8456-8460, 2000.

32. Kannappan $\mathrm{S}$ and Anuradha CV: Insulin sensitizing actions of fenugreek seed polyphenols, quercetin \& metformin in a rat model and metformin in rat model. Indian J Med Res 129: 401-408, 2009 
33. El Mesallamy HO, El-Demerdash E, Hammad L and El Magdoub HM: Effect of taurine supplementation on hyperhomocysteinemia and markers of oxidative stress in high fructose diet induced insulin resistance. Diabetol Metab Syndr 2: $1-11,2010$.

34 Lavigne C, Tremblay F, Asselin G, Jacques $\mathrm{H}$ and Marette A: Prevention of skeletal muscle insulin resistance by dietary cod protein in high fat-fed rats. Am J Physiol Endocrinol Metab 281: E62-E71, 2001.

35. Tremblay F, Lavigne C, Jacques H and Marette A: Dietary cod protein restores insulin-induced activation of phosphatidylinositol 3-kinase/AKT and GLUT 4 translocation to the T-tubules in skeletal muscle of high fat-fed obese rats. Diabetes 52: 29-37, 2003.

36. Hinault C, Mothe-Satney I, Gautier N and Van Obberghen E: Amino acids require glucose to enhance through phosphoinositide-dependent protein kinase 1 , the insulin-activated protein kinase B cascade in insulin-resistant adipocytes. Diabetologia 49: 1017-1026, 2006.

37. Shirai N, Terayama M and Takeda H: Effect of season on the fatty acid composition and free amino acid content of the sardine. Sardinops melanostictus. Comp Biochem Physiol B Biochem Mol Biol 131: 387-393, 2002.

38. Rajasekar P, Ravichandran MK and Anuradha CV: Intraperitoneal L-carnitine regulates lipid metabolism and reduces oxidative stress in fructose-induced hyperlipidemic rats. Diabetologia Croatica 34: 87-95, 2006.

39. Casaschi A, Maiyoh GK, Adeli K and Theriqult AG: Increased diacylglycerol acyltransferase activity is associated with triglyceride accumulation in tissue of diet-induced insulin-resistant hamsters. Metabol Clin Exp 54: 403-409, 2005.

40. Shukla A, Bettzieche A, Hirche F, Brandsch C, Stangl GI and Eder K: Dietary fish protein alters lipid concentrations and hepatic genes involved in cholesterol homeostasis in the rat model. Br J Nutr 96: 674-682, 2006
41. Ghanim H, Aljada A, Hofmeyer D, Syed T, Mohanty P and Dandona P: Circulating mononuclear cells in the obese are in a proinflammatory state. Circulation 110: 1564-1571, 2004

42. Patel P, Ghanim H, Ravishankar S, Sia CL, Viswanathan P, Mohanty P and Dandona P: Prolonged reactive oxygen species generation and nuclear factor- $\kappa \mathrm{B}$ activation after a high-fat, high-carbohydrate meal in the obese. J Clin Endocrinol Metab 92: 4476-4479, 2007.

43. Tripathy D, Mohanty P, Dhindsa S, Syed T, Ghanim H, Aljada A and Dandona P: Elevation of free fatty acids induces inflammation and impairs vascular reactivity in healthy subjects. Diabetes 52: 2882-2887, 2003.

44. Nguyen MT, Favelyukis S, Nguyen AK, Reichart D, Scott PA, Jenn A, Liu-Bryan R, Glass CK, Neels JG and Olefsky JM: A subpopulation of macrophages infiltrates hypertrophic adipose tissue and is activated by free fatty acids via toll-like receptors 2 and 4 and JNK-dependent pathways. J Biol Chem 282: 35279-35292, 2007.

45. Keaney F Jr, Larson MG, Vasan RS, Wilson PW, Lipinska I, Corey D, Massaro JM, Sutherland P, Vita JA and Benjamin EJ: Obesity and systemic oxidative stress: clinical correlates of oxidative stress in the Framingham Study. Arterioscler Thromb Vasc Biol 23: 434-439, 2003.

46. Hotamisligil GS, Arner P, Caro JF, Atkinson RL and Spiegelman BM: Increased adipose tissue expression of tumor necrosis factor-alpha in human obesity and insulin resistance. $\mathrm{J}$ Clin Invest 95: 2409-2415, 1995.

47. Rudkowska I, Marcotte B, Pilon G, Lavigne C, Marette A and Vohl MC: Fish nutrients decrease expression levels of tumor necrosis factor- $\alpha$ in cultured human macrophage. Physiol Genomics 40: 189-194, 2010. 